\title{
Cytotoxic Effect of Gliotoxin, Hemolysin, Protease and Melanin purified from Aspergillus fumigates on REF Cell Line, in vitro Study

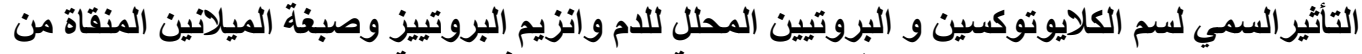

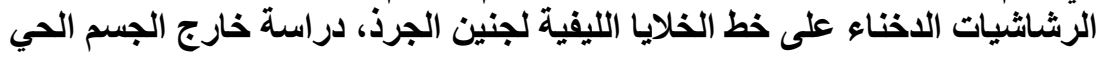

\author{
Batool Omran Theeb Farooq Ibrahem Mohammad * Abdulkareem Jasim Hashim ** \\ Department of Biology/ Iraqia University \\ * Biotechnology Research Center/ Al- Nahrain University \\ **College of science/ Baghdad University.

\begin{abstract}
Aspergillus fumigates especially clinical isolate produces a series of toxic substances and proteinaceous hemolysin, protease and pigment like melanin which appear to act in an additive and synergic way on cells. In this study, gliotoxin, hemolysin, Protease, and Melanin were used in an experimental model to study their Cytotoxic activity by evaluating their effect on REF cell line (Rat embryonic fibroblast), for exposure time of $24 \mathrm{hrs}$ at three different concentrations of each compounds triplicate of each concentration were used, cytotoxicity of the purified compounds were active against REF cell line under study and a toxic effect was clear with a significant difference at the level of probability $(p \leq 0.05)$ and this effect was contrasted among different concentrations for each purified compound growth inhibition of REF cell line was increase gradually with the increase of compound concentration.
\end{abstract}

Keywords: Gliotoxin, Hemolysin, Protease, Melanin, Cytotoxic activity

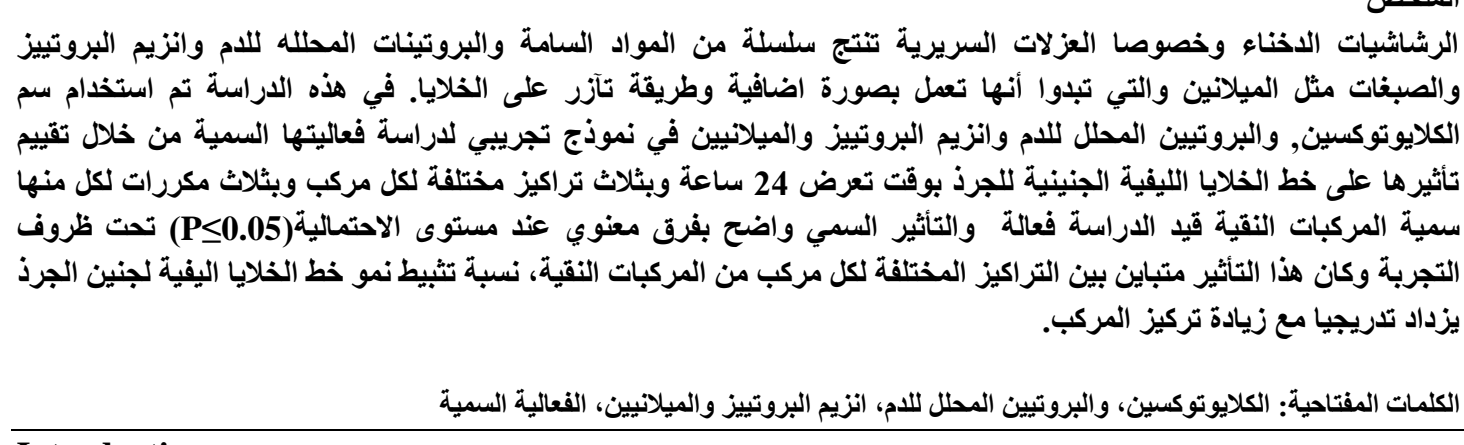

\section{Introduction}

Aspergillus fumigatus, a pathogenic and saprophytic mould [1] causing a wide range of diseases including aspergillosis, produces a series of toxic substances and array of chemicals [2] putative virulence factors of $A$. fumigatus are toxic molecules, which are often products of secondary metabolism. Gliotoxin inhibits the phagocytosis by macrophages and can induce their apoptosis. This effect could also be seen for polymorphonuclear leucocytes (PMN) [3,4,5,6]. The hemolysin, which enables the fungus to disrupt blood cells, contains negatively charged domains that the hemolysin has toxic effects, it seems not to be a main virulence factor but a compound that increases the effects of other toxic factors involved in pathogenicity [2,7,8,9]. Protease displaying different kinds of function seem important for full virulence of $A$. fumigatus. They are needed to obtain nutrients by degradation of collagen and elastin, which constitute the main compounds of the lung [10], and lead to a detachment of epithelium cells in the respiratory tract. $[11,12,13,14,15]$. Melanin conidial pigmentation, allows A. fumigatus to survive in phagocytes and thereby to escape from human immune effector cells and to become a successful pathogen [16]. Melanin, which likely enables the fungus to counteract the immune defense system and increases spore resistance $[17,18,19,20]$.

The advantages of tissue culture technique can be achieved as cytotoxic test of new chemicals, cosmetics, food additives in vitro [21,22]. 
This study aimed to determine the cytotoxic activity of the virulence factors of A. fumigaus and comparative between them.

\section{Materials and methods}

\section{Subculture of REF cell line}

Single cell suspension was prepared by treating $25 \mathrm{~cm}^{3}$ tissue culture flask with $2 \mathrm{ml}$ trypsin solution incubated for $2 \mathrm{~min}$ at $37^{\circ} \mathrm{C}$ in an incubator supplemented with $(5 \%) \mathrm{CO}_{2}$ after detachment of the cells from the flask surface by gently tapping of the flask followed by the addition of $20 \mathrm{ml}$ of growth medium supplemented with $10 \%$ fetal bovine serum, then the viability test of the cells was made by using trypan blue dye which stains the dead cells. Cells suspension was well mixed followed by transferring $200 \mu \mathrm{l} /$ well to the 96 well flat bottom micro titer plate using automatic micropipette containing $\left(1 \times 10^{5}\right.$ cell/well). Plates were incubated at $37^{\circ} \mathrm{C}$ in an incubator supplemented with (5\%) $\mathrm{CO}_{2}$ until 60-70\% confluence of the internal surface area of the well for REF cell line [23].

\section{Cytotoxicity assay}

To detect the growth inhibition of REF cell line, culture of this cell line was incubated with different concentrations of each compound used in our study these compounds done by different purification technique depended on the nature of the compound, cells were treated and incubated with the purified extracts of gliotoxin, hemolysin, protease, Melanin, three concentrations at triplicate form of each extracts to investigate the cytotoxic effect of these extracts respectively, the concentrations used as follows: gliotoxin $25,50,100 \mathrm{ng} / \mathrm{ml}$, hemolysin $2.5,5,10 \mu \mathrm{g} / \mathrm{ml}$, protease $7.5,15,30 \mu \mathrm{g} / \mathrm{ml}$ and melanin $62,125,250 \mu \mathrm{g} / \mathrm{ml}$ triplicate form of each concentration were used. Negative Control was achieved by incubating REF cell line with only maintenance medium.

\section{Detection of the Cytotoxic Effect}

Neutral red assay used to detect the cytotoxic effect. After elapsing the incubation period, $100 \mu 1 /$ well of neutral red dye freshly prepared were added to each well then plates incubated for 2 hrs, viable cells will uptake the dye while the dead not, the plates washed by PBS to remove the excess dye, then $100 \mu 1 /$ well of eluent solution was added to each well to withdraw the dye from the viable cells. Optical density of each well was measured by using ELISA reader at 492nm wave length [22,24].

Percentage of the inhibitory rate was measured according to Wang (2003) [25] as follows:

$$
\text { I.R \% }=\frac{\text { O.D. of control - O.D. of test }}{\text { O.D. of control }} \times 100
$$

\section{Statistical Analysis}

The values of the investigated parameters were given in terms of mean \pm standard error, and differences between means were assessed by analysis of variance (ANOVA) fallowed by Duncan test, using SAS computer program version 7.5 [26]. Differences in results were considered significant at probability value equal or less than 0.05 .

\section{Results and discussion}

\section{Cytotoxic Effect of Gliotoxin}

Results in Figure (1) show that growth inhibition of REF cell line decreased gradually when gliotoxin concentration increased. Gliotoxin has significant differences of cytotoxic effect on REF cell line $(\mathrm{P} \leq 0.05), 81 \%, 63.21 \%$ and $40 \%$ growth inhibition was showed at concentrations 100, 50, and 25 $\mathrm{ng} / \mathrm{ml}$ respectively. 


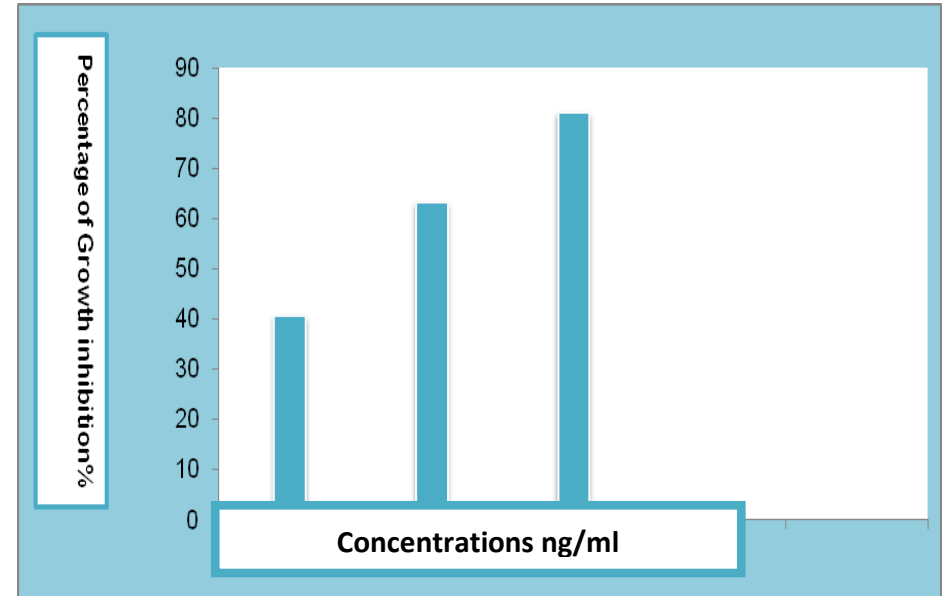

Fig. (1): Cytotoxicity effect of different concentrations of purified Gliotoxin from A.fumigatus on the REF cell line after $24 \mathrm{hr}$.

The biological activity of any chemical compound is based on active groups and an internal bond, gliotoxin have an internal disulfide bond that can bind and inactivate proteins via a sulfide:thiol exchange [27], therefore the cytotoxic effect of gliotoxin maybe attributed to its disulfide bond. The disulfide bridge allows the cross linking with proteins via cysteine residues and generate deleterious reactive oxygen species (ROS) through the redox cycling between the reduced and oxidized form. This mechanism of ROS generation is believed to be responsible for the toxicity of gliotoxin [28]. The ROS generated as a result reported to facilitate the release of cytochrome c and apoptosis inducing factors from mitochondria, leading to caspase activation, as well as other events that mediate cell death [29].

Cytotoxic effect of gliotoxin in our result may be attributed to the ability of gliotoxin to induce morphological changes in the cells, These changes in normal cell line are due to a loss in the adherence of the cells to their plastic container [30], which is characteristic of an apoptotic process [31].

This phenomenon has been described for gliotoxin on different cell types: thymocytes, lymphocytes, spleen cells, or macrophages [29]. Gliotoxin inhibited oxidative burst of human neutrophils, gliotoxin also causes damage to the ciliated respiratory epithelium in vitro and this property might assist $A$. fumigatus in the colonization of the respiratory mucosa . Furthermore, Nierman (2008) [32] have shown by the genome-wide gene expression profile analysis that gliotoxin genes are upregulated in germination during initiation of infection in mice [33] .

\section{Cytotoxic Effect of Hemolysin}

Significant cytotoxic effect $(\mathrm{P} \leq 0.05)$ was observed on the growth of REF cell line at the concentrations of $2.5,5$, and $10 \mu \mathrm{g} / \mathrm{ml}$ with growth inhibition percentage $33.79 \%, 64.44 \%$ and $76.68 \%$, respectively, as shown in the Figure (2).There was an increase in the inhibitory effect when compared with the control. Hemolysin is cytolytic and hemolytic protein and can induce effective permeabilization in cell [2], these activities of hemolysin help us to explain the cytotoxic effect of hemolysin in our results. Hemolysin is cytolytic and hemolytic protein and can induce effective permeabilization in the cell [2], these activities of hemolysin help us to explain the cytotoxic effect of hemolysin in our results. 


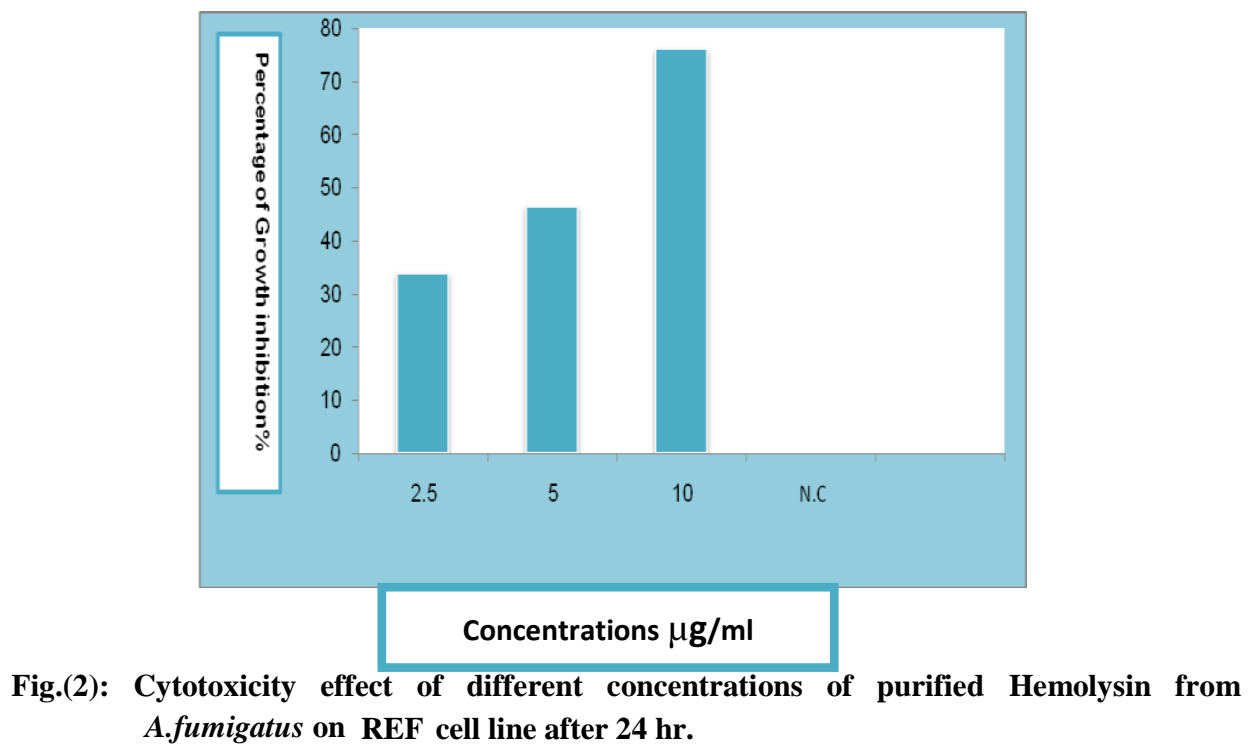

Hemolysin has an alpha helical structure, Alpha helical toxin cause damage in susceptible cells by creating pores in membranes. Donohue et al.. (2006) [34] experiments showed that specific interaction of hemolysin with plasma membrane domains occur, suggesting that hemolysin has a specific binding protein [35]. The existence of phospholipid membrane domains involved in cell signaling, endocytosis and attachment of several toxins and protein indicate that these cells membrane domains probably serve as attachment sites for hemolysin, leading to their aggregation and formation of the pore $[36,37,38]$.

\section{Cytotoxic Effect of Protease}

Figure (3) showed protease, with enzymetic activity of $226.98 \mathrm{U} / \mathrm{ml}$ purified from A. fumigatus had cytotoxic effect on growth of REF cell line at the concentrations of $7.5,15$, and $30 \mu \mathrm{g} / \mathrm{ml}$ with growth inhibition percentage of $37.17 \%, 47.81 \%$ and $56.35 \%$, respectively Growth inhibition of REF cell line was increased gradually with the increases of the enzyme concentration.

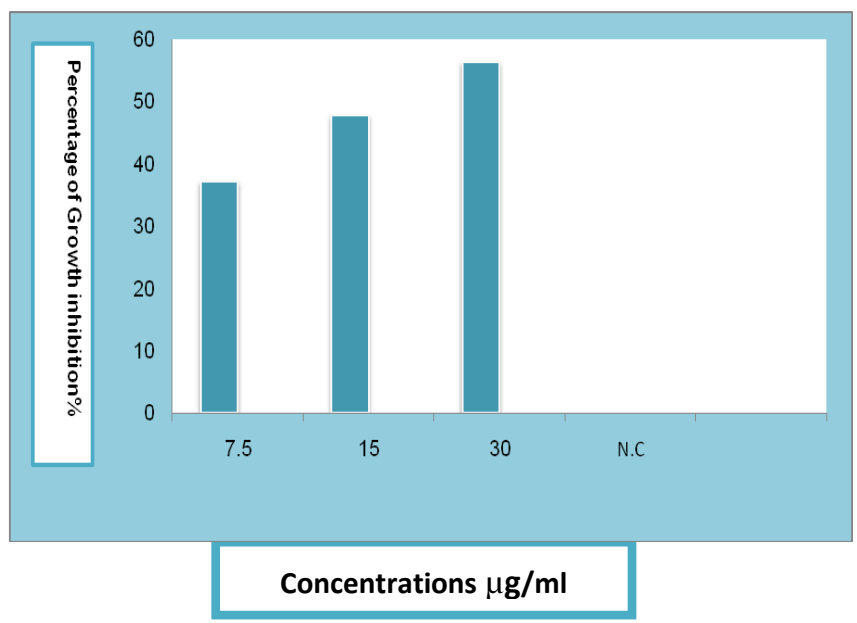

Fig. (3): Cytotoxicity effect of different concentrations of purified Protease from A.fumigatus on the REF cell line after $24 \mathrm{hr}$.

No significant cytotoxic effect $(\mathrm{P} \leq 0.05)$ between the concentrations 7.5 and $15 \mu \mathrm{g} / \mathrm{ml}$, of prote ase and no significant cytotoxic effect between the concentrations 15 and $30 \mu \mathrm{g} / \mathrm{ml}$ when compared with the control.

Protease have proteolytic activity, this activity enable it to degrate the main compounds of the cell [10]. The results may be agreed with the results of Balachandran et al.. (2012) [39], who found that there is significant cytotoxic effects of protease on A549 cell line, the cytotoxicity of protease was concentration dependent, also protease inhibit growth of normal cell line. Grigoryan et al.. [40] reported that any decrease in the activity of protease accompanied by a decrease in the growth inhibition. level in vitro ,the mechanism of protease activity depends on a set of amino-acid residues, 
typically Ser-His-Asp, known as the "catalytic triad" [41]. This set includes a nucleophilic residue (Ser), a general base (His), and an additional, acidic, residue (Asp), all connected by a chain of hydrogen bonds [42].

\section{Cytotoxic Effect of Melanin}

REF cell line treated with melanin at the concentrations of 62,125 , and $250 \mu \mathrm{g} / \mathrm{ml}$ and showed growth inhibition percentage of $4.95 \%, 7.38 \%$ and $31.11 \%$, respectively. Growth inhibition of REF cell line was increased gradually with the increase of melanin concentration as shown in the Figure (4). Results showed significant cytotoxic effect $(\mathrm{P} \leq 0.05)$ between the concentrations when compared with the control.

Our results may be agreed with the results of some studies which showed that melanin had slight cytotoxic effect, melanin revealed an elevated susceptibility to reactive oxygen intermediates (ROI) which derived from hydrogen peroxide from cells [43].

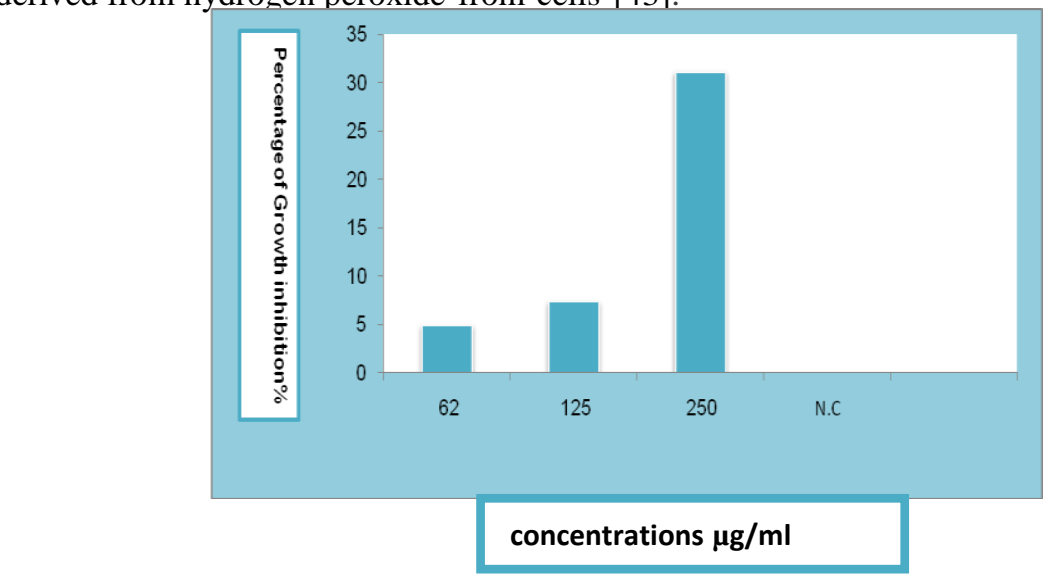

Fig.(4): Cytotoxicity effect of different concentrations of purified Melanin from A.fumigatus on REF cell line after $24 \mathrm{hr}$.

Langfelder et al.. (2003) [44] showed that melanin has no significant effect on normal cell line after 48 hours of incubation. Figure (5) indicated that there is significant difference between the effect of purified compound on the normal cell line.

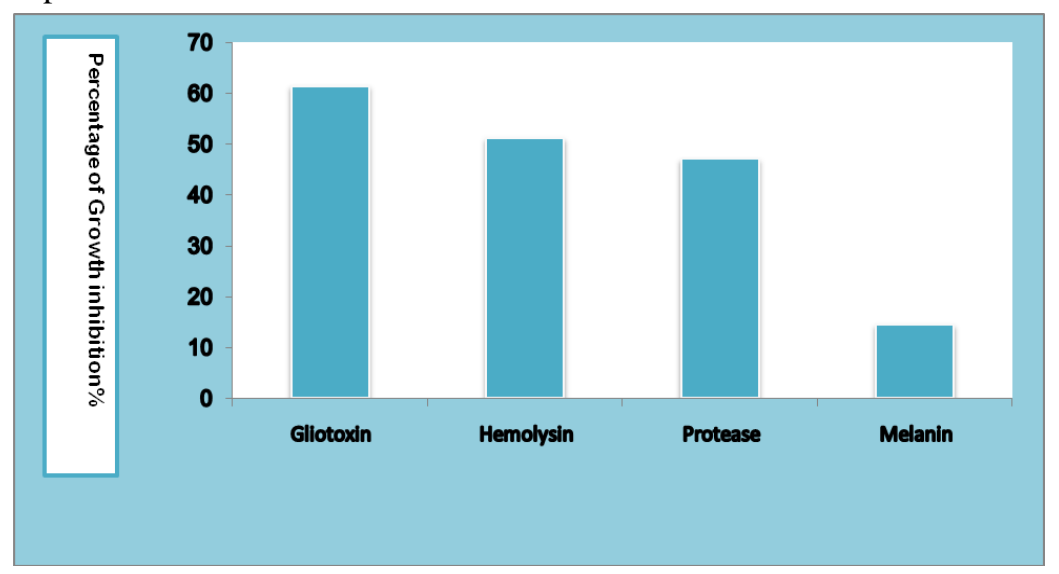

Fig. (5): Comparasion between the cytotoxic effect of purified compound in our study

The differences between the effects of compounds may be due to the chemical composition of each compounds, gliotoxin showed the highest growth inhibition percentage when compared with the other compound.

\section{Conclusion}

All purified compounds showed cytotoxic effect and depended on the nature of each compound, gliotoxin showed highest cytotoxic effect when compared with the other compounds in the study, our results indicate that gliotoxin might be considered as a possible virulence factor of Aspergillus fumigatus during the infection. 


\section{References}

1. Dyer, P.S., and Paoletti, M. (2005). Reproduction in Aspergillus fumigatus: sexuality in a supposedly asexual species. Med Mycol 43 Suppl. 1: S7-14.

2. Malic `ev, M., Chowdhury, H.H., Macek, P. and Sepcic, K. (2007). Effect of ostreolysin, an Asphemolysin isoform, on human chondrocytes and osteoblasts, and possible role of Asp-hemolysin in pathogenesis. Medical Mycology.J. 45, 123_130.

3. Eichner, R.D., Al Salami, M., Wood, P.R., and Mullbacher, A. (1986). The effect of gliotoxin upon macrophage function. Int J Immunopharmacol. 8: 789-797.

4. Kamei, K., and Watanabe, A. (2005). Aspergillus mycotoxins and their effect on the host. Med Mycol 43 Suppl 1: S95-99.

5. Orciuolo, E., Stanzani, M., Canestraro, M., Galimberti, S., Carulli, G., Lewis, R., Petrini, M., and Komanduri, K.V. (2007). Effects of Aspergillus fumigatus gliotoxin and methylprednisolone on human neutrophils: implications for the pathogenesis of invasive aspergillosis. J Leukoc Biol. 82: 839-848.

6. Waring, P., Eichner, R.D., Müllbacher, A., and Sjaarda, A. (1988). Gliotoxin induces apoptosis in macrophages unrelated to its antiphagocytic properties. J Biol Chem. 263:18493-18499.

7. Ebina, K., Yokota, K., and Sakaguchi, O. (1983). Studies on toxin of Aspergillus fumigatus. XVI. Biological properties of Asp-hemolysin as a parasitic factor. Jpn J. Med Mycol. 24: 247-252.

8. Fukuchi, Y., Kumagai, T., Ebina, K., and Yokota, K. (1996). Apolipoprotein B inhibits the hemolytic activity of asp-hemolysin from Aspergillus fumigatus. Biol Pharm Bull. 19:547-550.

9. Yokota, K., Ichinowatari, S., Ebina, K., and Wakabayashi, N. (1985). Studies on toxin of Aspergillus fumigatus. XXI. Site of binding of Asp-hemolysin to erythrocytes and mechanism of inhibition of hemolysis. Jpn J Med. Mycol. 26: 70-73.

10. Monod, M., Fatih, A., Jaton-Ogay, K., Paris, S., and Latgé, J.P. (1995).The secreted proteases of pathogenic species of Aspergillus and their possiblerole in virulence. Can J Bot. 73:1081-1086.

11. Grant, C.M. (2001). Role of the glutathione/ glutaredoxin and thioredoxin systems in yeast growth and response to stress conditions. Mol Microbiol. 39: 533-541.

12. Smith, J.M., Tang, C.M., Van Noorden, S., and Holden, D.W. (1994). Virulence of Aspergillus fumigatus double mutants lacking restriction and an alkaline protease in a low-dose model of invasive pulmonary aspergillosis. Infect Immun. 62: 5247-5254.

13.Tang, C.M., Cohen, J., and Holden, D.W. (1992). An Aspergillus fumigatus alkaline protease mutant constructed by gene disruption is deficient in extracellular elastase activity. Mol Microbiol. 6: 1663-1671.

14.Tang, C.M., Cohen, J., Krausz, T., Van Noorden, S., and Holden, D.W. (1993). The alkaline protease of Aspergillus fumigatus is not a virulence determinant in two murine models of invasive pulmonary aspergillosis. Infect Immun. 61: 1650-1656.

15.Tekaia, F., and Latgé, J.P. (2005) . Aspergillus fumigatus: saprophyte or pathogen? Curr Opin Microbiol. 8: 385-392.

16.Heinekamp,T., Thywißen, A., Macheleidt, J., Keller, S.,Valiante,V. and Brakhage, A.A. (2012). Aspergillus fumigatus melanins: interference with the host endocytosis pathway and impact on virulence . Microbio. J. 3:440.

17. Hogan, L.H., Klein, B.S. and Levitz, S. M. (1996).Virulence factors of the medically important fungi. Clin. Microbiol. Rev. 9: 469-488.

18. Latgé, J.P. (1999). Aspergillus fumigatus and aspergillosis. Clin Microbiol Rev. 12: 310-350.

19.Tsai, H.F., Washburn, R.G., Chang, Y.C. and Kwon-Chung, K.J. (1997). Aspergillus fumigatus arpl modulates conidial pigmentation and complement deposition. Mol Microbiol. 26: 175-183.

20.Verweij, P.E., Oakley, K.L., Morrissey, J., Morrissey, G., and Denning, D.W. (1998). Efficacy of LY303366 against amphotericin B-susceptible and -resistant Aspergillus fumigatus in a murine model of invasive aspergillosis. Antimicrob Agents Chemother. 42:873-878.

21.Butter, M. (1996). Animal cell culture and technology, the basic. IRL press at Oxford Univ. press. New York.

22.Freshney, R.I. ( 2010). Culture of animal cells. 6th Edition. Wiley- Liss. New York.

23. Freshney, R. I. (2000). "Culture of animal cells: A manual for basic technique" $4^{\text {th }}$ Ed. Wiley- Liss, A John wiley and Sons, Inc. Publication, New York.

24. Mahony, D. E., Gilliatt, E., Dawson, S., Stockdale, E. and Lee, H.S. (1989). Vero cell assay for rapid detection of Clostridium perfringins enterotoxin. Appl. Environ. Microbiol. J. 55:2141-214. 
25.Wang, B., Relling, M.V. and Storm, M.C. (2003). Evaluation of immunologic cross reaction of antiasparaginase antibodies in acute lymphoblastic leukemia (ALL) and lymphoma patients. Leukemia. J. 17:1583-1588.

26. SAS users. (2004). Guide personal computer (ver.7) inst. Inc. Cary. Nc. USA.

27.Kwon-Chung, K. and Janyce Sugui, A. J. (2009). What do we know about the role of gliotoxin in the pathobiology of Aspergillus fumigatus? Med Mycol. 2009 , 47(Suppl 1): S97-103.

28. Collins, J.A., Schandl, C.A., Young, K.K.,Vesely, J., Willingham, M.C. (1997). Major DNA fragmentation is a late event in apoptosis. J. Histochem. Cytochem. 45 (7): 923-934.

29. Golden, M.C., Hahm, S.J., Elessar, R.E., Saksonov, S., Steinberg, J.J. (1998). DNA damage by gliotoxin from Aspergillus fumigatus. An occupational and environmental propagule: adduct detection as measured by 32P DNA radiolabelling and two-dimensional thinlayer chromatography. Mycoses. 41: 97-104.

30.Jordan, T.W., Pedersen, J.S., (1986). Sporidesmin and gliotoxin induce cell detachment and perturb microfilament structure in cultured liver cells. J. Cell Sci. 85, 33-46.

31. Shepherd, V.L., Vandre, D.D., Eltin, G.J.J., Montgomery, R. ( 1980). Effects of cesalin on the ultrastructure and biological properties of cultured mammalian cells. Cancer Res. 40: 225-231.

32.Nierman, WC, Fedorova, N. (2008). 3rd Advances Against Aspergillosis. Miami Beach, Florida: Subtelomeric diversity as a major force in evolution of Aspergillus secondary metabolism and virulence pathways. P.77.

33.Pardo, J., Urban, C., Galvez, E.M. (2006). The mitochondrial protein Bak is pivotal for gliotoxininduced apoptosis and a critical host factor of Aspergillus fumigatus virulence in mice. J. Cell Biol.174:509-519. (PubMed: 16893972).

34. Donohue, M., Wei, W., Wu, J., Zawia, N.H., Hud, N., Jesus, V.D., Schmechel, D., and Vesper, S. (2006). Characterization of nigerlysin, hemolysin produced byAspergillus niger, and effect on mouse neuronal cells in vitro. J.Toxicology. $219: 150-155$.

35.Van Engeland, M, Ramaekers, F.C., Schutte, B. (1996). A novel assay to measure loss of plasma membrane asymmetry during apoptosis of adherent cells in culture. Cytometry. 24: 131_139.

36. Ebina, K., Sakagami, H., Yokota, K. ( 1994). Cloning and nucleotide sequence of cDNA encoding Asp-hemolysin from Aspergillus fumigatus. Biochim Biophys Acta. 1994; 1219: 148_150.

37.Ebina, K., Yokota, K., Sakaguchi, O. (1982). Studies on the toxin of Aspergillus fumigatus. XIV. Relationship between Asp-hemolysin, and experimental infection of mice. Jpn J. Med Mycol. 23:246_252.

38.Berne, S., Sepc ic, K., Anderluh, G. (2005). Effect of $\mathrm{pH}$ on the pore forming activity and conformational stability of ostreolysin, alipid raft-binding protein from the edible mushroom Pleurotus ostreatus. Biochemistry. 44: 11137_11147.

39.Balachandran, C., Duraipandiyan, $\bar{V}$. and Ignacimuthu, S. (2012). Purification and characterization of protease enzyme from actinomycetes and its cytotoxic effect on cancer cell line (A549).J. Asian Pacific Journal of Tropical Biomedicine. S392-S400.

40.Grigoryan, R. S., Panosyan, E. H., Seibel, N. L., Gaynon, P. S., Avramis, I. A. and Avramis, V. I. (2004). Changes of amino acid serum levels in pediatric patients with higher-risk acute lymphoblastic leukemia (CCG-1961). In Vivo J. 18(2):107-12.

41.Carter, P. and Wells, J. A. (1988). Dissecting the catalytic triad of a serine protease. Nature J. 332:564568.

42.Dhavala, P. (2010). Structural studies on enzymes of Biotechnological and Biomedical interest. Ph.D. thesis. Turku University. Turkey.

43.Jacobson, E. S. (2000). Pathogenic roles for fungal melanins. Clin. Microbiol. Rev. 13:708-717.

44.Langfelder, K., M. Streibel, B. Jahn, G. Haase, and A. A. Brakhage. (2003). Biosynthesis of fungal melanins and their importance for human pathogenic fungi. Fungal Genet. Biol. 38:143-158. 